\title{
Evaluation of fermented cassava (Manihot esculenta) peel meal on the growth of Clarias gariepinus
}

\author{
Adejoke A. Adewumi \\ Department of Zoology and Environmental Biology, Ekiti State University, Ado Ekiti, Nigeria. Email: \\ zoewumi@gmail.com.
}

\begin{abstract}
Copyright (c) 2018 Adewumi. This article remains permanently open access under the terms of the Creative Commons Attribution License 4.0, which
\end{abstract} permits unrestricted use, distribution, and reproduction in any medium, provided the original work is properly cited.

Received 3rd May, 2018; Accepted 26th July, 2018

\begin{abstract}
An experiment was conducted to evaluate the impact of cassava (Manihot esculenta, (NR 8082) peel, fermented with wastewater from the fermented cassava pulp, as a substitute for maize in the diet of $C$. gariepinus juveniles on the growth performance of C. gariepinus. Five iso-caloric and iso-nitrogenous diets were formulated containing $25 \%$, $50 \%, 75 \%$ and $100 \%$ maize replacement with cassava peel meal (tagged diets B25, C50, D75, E100). The control was tagged diet A0. Two sets of experiment were designed using the formulated diets. One set, which lasted for 10 days, was designed to monitor the apparent protein digestibility of the diet and the second one to evaluate the growth, nutrient utilization (MWG, FCR, SGR) and the biochemical composition of the fillets of the fish, fed for a period of 8 weeks, in the

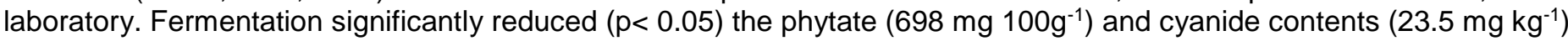

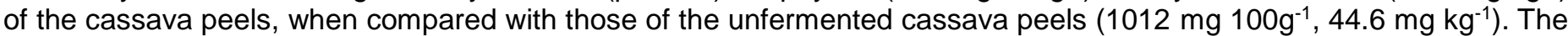
final weight gain $(13.47 \mathrm{~g})$, daily weight gain $(0.19 \mathrm{~g})$, percentage weight gain $(243.62 \%)$, food conversion ratio $(5.67)$, protein efficiency ratio (1.20) and the apparent protein digestibility (APD) of the fish fed with the control diet (diet A0) were not significantly $(P>0.05)$ higher than those of the fish fed diets B25 and C50, but were significantly $(P<0.05)$ higher than those of the fish fed diets D75 and E100. The specific growth rate and survival in all the treatments were not significantly different $(P>0.05)$ from one another. The results revealed that $50 \%$ replacement of maize with cassava peel meal (diet C50) can be tolerated by $C$. gariepinus, without compromising growth, nutrient utilization and digestibility. The percentage survival of the fish fed the control, test diets B25, C50 and D75 were not significantly different $(p>0.05)$ but were significantly different from those fish fed diet E100. It can be concluded that replacing maize with up to $50 \%$ replacement level of cassava peels fermented with wastewater from the fermented cassava pulp is not deleterious to growth and nutrient utilization of $C$. gariepinus. Fermentation might have thus reduced the toxicity and increased the nutrient value of the cassava peels, otherwise regarded as agricultural wastes, and placed it among basal feedstuffs, suitable for replacing maize in C. gariepinus diet.
\end{abstract}

Key words: Cassava peel, catfish, cyanide, digestibility, fillets, growth, peel, phytate

\section{INTRODUCTION}

The cassava root is a good source of carbohydrate and has an estimated average composition of 60 to $65 \%$ moisture, 30 to $35 \%$ carbohydrate, 0.2 to $0.6 \%$ ether extract and 1 to $5 \%$ crude protein. It has relatively low content of minerals and vitamins, although it is fairly rich in calcium and ascorbic acid. Charles et al. (2005) reported that the calcium content is relatively high (15 and $35 \mathrm{mg}^{100 \mathrm{~g}}$ of edible portions) compared to that of other staple crops. The ascorbic acid content is also high and between 15 and $45 \mathrm{mg}^{100 g}$ edible portions (Charles et al., 2005). It contains low amount of the B vitamins (thiamine, riboflavin and niacin) and part of this is lost during processing (Montagnac et al., 2009). However, cassava contains undesirable compounds such as hydrocyanic acid (HCN) released through acid or enzyme hydrolysis of the cyanogenic glycosides, linamarin and lotaustralin, which could devalue it as animal feed (Oboh et al., 2002).

Cassava by-products are readily available in factories where cassava tubers are processed into starch or flour. Two important biological wastes that may cause damage 
to the environment are generated during the traditional processing of cassava roots for 'gari' (coarse flour), 'fufu' etc production in Africa, namely, the cassava peels and the liquid squeezed out of the fermented parenchyma mash. Cassava peels are normally discarded as wastes and allowed to rot in the open, thus resulting in health hazards (Cumbana et al., 2007). The licheate from these rotten wastes contains compounds that are generally toxic to living organisms. This will also, at toxic concentrations, prevent germination as well as inhibit growth of some living organisms. Continuous discharge of the effluent into the soil for a long period of time leads to the extinction of some bacteria and fungi types that were originally available in the soil. When cassava effluent is released directly into streams and rivers, it would cause rapid growth of bacteria, resulting in oxygen depletion and death of fish and other aquatic life (Adeyemo, 2005). Annual cassava production in Africa is about 84 million tonnes, with Nigeria having the highest production of 30 million tonnes, Tanzania, 5.7 million tonnes and Madagascar, 2.4 million (Adeyemo, 2005). Since peels could make up to 5 to $10 \%$ of the wet weight of the roots (Aro et al., 2010; Nwokoro et al., 2005), they constitute an important potential resource for animal feeds, if properly processed by a bio-system (Antai and Mbongo, 1994). Fresh cassava peels spoil very quickly. They contain phytates (hexaphosphates of myo-inositol) and high amounts of cyanogenic glycosides than the parenchyma (pulp), but have higher protein content than other tuber parts (Tewe, 1992). They should thus be processed in order to reduce cyanogenic potential and phytate content and preserve their nutritive quality. The different processes used; sun-drying, ensiling and soaking/sun-drying have been reported by Tewe (1992) and Motarjemi (2002), to be effective in reducing cyanogenic glycosides. Fermentation is one of the oldest applied biotechnologies, having been used in food processing and preservation, as well as beverages production for over 6,000 years (Achinewhu et al., 1998). Achinewhu et al. (1998) further stated that fermentation enhances the nutrient content of foods through the biosynthesis of vitamins, essential amino acids and proteins, by improving protein quality and fibre digestibility. The apparent increases in crude protein content during fermentation appeared to be due to the loss of 35 to $40 \%$ dry matter (DM) of the substrate which resulted in 'enrichment' of the crude protein fraction during the course of fermentation (Sengxayalth and Preston, 2017). Oboh et al. (2002) reported that the cell membrane of microorganisms contains lipid, organic, inorganic compounds and some elements such as lipid component consisting of triglyceride. The increase in the fat content might due to the increase in the microbial mass, activities of lipolytic microorganisms to secrete extracellular enzyme (lipase), secretion of microbial oil into the fermenting medium and other products from the metabolism. Fermentation also enhances micronutrient bioavailability and aids in degrading anti-nutritional factors (Ngiki et al.,
2014).

High cost of fish feed has been observed as one of the problems limiting aquaculture development in Nigeria (Adewumi and Fagbenro, 2010). High cost of feeds marginalize or even nullify the profitability of the growing fish farming enterprise since feed accounts for at least $60 \%$ of the total cost of production. Apart from the high and fluctuating costs, some of the ingredients used in mixed feeds, notably cereal grains, are in high demand for human consumption. Maize imported into Africa in 2011 is estimated to be about $\$ 4.63$ billion, of which Nigeria's feed industry alone accounted for 1.2million tonnes (\$350million) during that year (Phonekhampheng et al., 2008).

This has motivated the search for locally available, cheap and suitable alternative protein/energy source for fish feed formulation. In view of the above, the present research was set up with the objectives of determining the optimum replacement level of maize, an energy-rich source, by cassava peels (an agricultural waste product) in the diet of $C$. gariepinus. An experiment was thus conducted to evaluate the impact of ensiled cassava (Manihot esculenta, NR 8082) peel (an agricultural waste product) as substitute for maize in the diet of $C$. gariepinus juveniles, on the growth, nutrient digestibility and utilization of the fish.

\section{MATERIALS AND METHODS}

\section{Experimental setup}

Two sets of experiment were designed using the formulated diet in feeding $C$. gariepinus. One set, which lasted for 10 days, was designed to monitor the apparent protein digestibility (APD) of the diet and the other one to evaluate growth and biochemical composition of the flesh of the fish.

\section{Procurement and processing of materials}

A total of seven hundred catfish juveniles were procured for the two experiments. These were purchased from the Department of Fisheries, Crown Polytechnic, llawe-Ekiti and brought to the Aquaculture Centre, Ekiti State University, SLT Campus, Ifaki Ekiti. The juvenile fish were acclimatized for two weeks being fed with commercial fish feed (Coppens) at a rate of $5 \%$ average body weight/ day. All other feedstuffs [maize, brewery waste, Danish fish meal ( $68 \%$ crude protein), soya, ground nut cake (GNC), bone, salt, lysine, methionine and mineral/vitamin premix] used to prepare the experimental feed, were purchased from MetroVet Ventures, Ado-Ekiti. The cassava peels were collected from a local cassava processing factory located at Ifaki-Ekiti. The peels were washed and sundried for about 5 hours to wilt. Some of these peels were milled 
directly into powder form. The remaining of about $3 \mathrm{~kg}$ was mixed with poultry droppings (to provide nitrogen) and liquid obtained from fermentation of cassava pulp, in 'gari' processing. This mixture was kept wrapped inside black waste disposal bag for 21 days, at room temperature. After 21 days of fermentation, the product was sundried and milled into powdery meal named ensiled cassava peel meal (ECPM). The biochemical analysis of the meal was done to know the crude protein content, as shown in Table 1. The ECPM was subsequently mixed with other ingredients using Pearson's Square method of feed formulation. Different proportions of the ingredients were weighed and mixed into a fine consistency to form diets B25, C50, D75, E100 composed of a replacement of maize meal with ensiled cassava peel meal (Table 2). The control diet is tagged A0. Pelleting was done, using a $2 \mathrm{~mm}$ die pellet disc in a Hobart A120 pelleting machine (Hobart Manufacturing Ltd., London England). The pelleted feeds were then sundried and stored in labeled bags in the deep freezer until when needed for experimental feeding. To test the apparent protein digestibility (APD) of the diets, $1 \%$ trivalent chromic oxide $\left(\mathrm{Cr}_{2} \mathrm{O}_{3}\right)$ was included in the above diets, used for another experimental set up in outdoor tanks.

\section{Experimental design, feeding and monitoring}

After two weeks of acclimatization, twenty (20) juveniles of C. gariepinus (average weight of $3.13 \pm 0.23 \mathrm{~g}$ ) were randomly distributed into each, well labeled, plastic aquarium tank $(60 \mathrm{~cm} \times 30 \mathrm{~cm} \times 30 \mathrm{~cm}$ ) filled with $2 / 3$ volume of water, in triplicates per treatment, making up 60 pieces for each treatment. These were fed at $3 \%$ body weight/day in two installments, at $8.00 \mathrm{am}$ in the morning and $4.00 \mathrm{pm}$ in the evening, for a period of 10 weeks. For the experimental set used for APD studies, 45 pieces of fish were used per treatment. They were randomly distributed in groups of 15 into three aquarium tanks.

The fish were allowed to eat for 6 hours after which the left over diets in the tanks were collected by siphoning, oven-dried, pooled together, weighed and stored at $-20^{\circ} \mathrm{C}$. After the removal of uneaten diets, faecal samples were collected continuously at a 3 to 4 hours interval for a period of 17 to 18 hours. Mortality of fish in the experimental bowl was monitored daily and recorded. Cleaning of the medium and data collection were done bi-weekly. The weights $(\mathrm{g})$ of three samples from each tank were taken and daily rations were adjusted accordingly.

\section{Growth performance evaluation/feed efficiency}

The growth performance parameters were evaluated using the following formula

Mean weight gain, MWG $(\mathrm{g})=$ Mean final weight - Mean initial weight
Daily weight gain, $\mathrm{DWG}(\mathrm{g})=\frac{\mathrm{MWG}(\mathrm{g})}{\text { Number of days }}$

Percentage weight gain $(\mathrm{PWG})=\frac{\mathrm{MWG}(\mathrm{g}) \times 100}{\text { Mean initial weight }}$

Mortality rate $=\frac{\mathrm{ITF}-\text { FTF }}{\mathrm{ITF}} \times 100$

Where: ITF = initial total number of fish and FTF= final total number of fish

SGR $=\frac{\text { Loge (final body weight })- \text { loge (initial body weight) }}{\text { Time period (in days) }} \times 100$

$\mathrm{FCR}=\frac{\text { Feed given (Dry weight) }}{\text { Weight gain }}$

Where: SGR = Specific growth rate and FCR $=$ Food conversion ratio.

\section{Apparent Protein Digestibility (APD)}

APD of the diet was calculated from the proportion of $\mathrm{Cr}$ and protein in the diet and faeces following the equation (AOAC, 2006):

$A P D_{D}=1-\left(D C_{F} \times I_{D}\right) /\left(D C_{D} \times I_{F}\right)$

Where: $A P D_{D}$ is the apparent digestibility of the dietary component, $\mathrm{DC} F$ is the dietary component concentration in faeces, $I_{D}$ is the indicator concentration in diet, $D C_{D}$ is the dietary component concentration in diet and $\mathrm{IF}_{\mathrm{F}}$ the indicator concentration in faeces.

\section{Biochemical analysis}

The proximate composition (crude protein, ash, moisture, lipid and fibre) of the ECPM and the diets were carried out by the method of AOAC (2006). Phytic acid content of the unfermented, sundried cassava peel meal and ECPM was analyzed by the method of Wheeler and Ferrel (1971). The cyanide content was determined by silver nitrate titration (Charles et al., 2005). Chromium was determined in the diets and faecal samples by the method of Saha and Gilbreath (1991). Samples of diet $(500 \mathrm{mg}$ ) or of lyophilized faeces $(250 \mathrm{mg})$ were ashed in a muffle furnace at $450^{\circ} \mathrm{C}$. Then $15 \mathrm{ml}$ of nitric acid $(70 \%)$ and $5 \mathrm{ml}$ of perchloric acid $(60 \%)$ were added to the ashed sample. The samples were then digested at $100^{\circ} \mathrm{C}$ for approximately 6 hours until the green color changed to orange. The concentration of chromium in the sample was determined by Atomic Absorption Spectrophotometer (AAS) (Varian Spectra AA 240) at $425.4 \mathrm{~nm}$ using air acetylene flame. 
Table 1. The proximate composition $\left(\mathrm{g} / 100 \mathrm{~g} \mathrm{dm} \mathrm{m}^{*}\right)$ of cassava peels used in formulating the experimental diets.

\begin{tabular}{lcc}
\hline \multirow{2}{*}{ Parameter } & \multicolumn{2}{c}{ Composition } \\
\cline { 2 - 3 } & Unfermented Sun-dried & Fermented \\
\hline Crude protein & 5.3 & 11.4 \\
Lipid & 1.2 & 3.5 \\
Ash & 5.9 & 6.3 \\
Crude Fibre & 20.9 & 7.1 \\
Moisture & 5.2 & 5.7 \\
Carbohydrate & 61.5 & 66.0 \\
\hline
\end{tabular}

$\mathrm{dm}=$ dry matter.

Table 2. Ingredients composition $(\mathrm{g} / 100 \mathrm{~g} \mathrm{dm})$ and proximate composition of the experimental diets fed to $C$. gariepinus, during the period of study.

\begin{tabular}{lccccc}
\hline \multirow{2}{*}{ Ingredients } & \multicolumn{5}{c}{ Diets } \\
\cline { 2 - 6 } & A0 & B25 & C50 & D75 & E100 \\
\hline Maize & 59.00 & 44.25 & 29.50 & 14.75 & - \\
ECPM & - & 14.75 & 29.50 & 44.25 & 59.00 \\
Fishmeal & 37.00 & 37.00 & 37.00 & 37.00 & 37.00 \\
Common salt & 0.50 & 0.50 & 0.50 & 0.50 & 0.50 \\
Vegetable oil & $1: 00$ & $1: 00$ & $1: 00$ & $1: 00$ & $1: 00$ \\
Vitamin premix & 1.00 & 1.00 & 1.00 & 1.00 & 1.00 \\
Vitamin C & 0.50 & 0.50 & 0.50 & 0.50 & 0.50 \\
Methionine/Cysteine & $1: 00$ & $1: 00$ & $1: 00$ & $1: 00$ & $1: 00$ \\
& & & & & \\
Proximate composition & & & & & \\
Crude protein & 38.91 & 45.06 & 38.06 & 37.19 & 38.94 \\
Moisture & 23.91 & 11.21 & 10.13 & 10.26 & 10.08 \\
Ether extract & 7.15 & 15.08 & 13.31 & 15.83 & 6.55 \\
Crude fiber & 2.16 & 1.94 & 1.82 & 1.91 & 3.02 \\
Ash & 8.78 & 9.68 & 10.13 & 10.34 & 10.72 \\
Nitrogen Free extract & 19.09 & 17.03 & 26.55 & 24.47 & 30.69 \\
\hline
\end{tabular}

$\mathrm{dm}=$ dry matter.

\section{Statistical analysis}

Data generated were subjected to a non-parametric t-test (Mann-Whitney U- Wilcoxon Rank Sum W- test) for comparison of means within treatment while the TurkeyHSD one-way ANOVA was used for between treatments comparison at the $5 \%$ level of significance.

\section{RESULTS AND DISCUSSION}

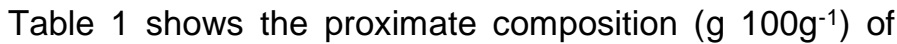
ECPM used in formulating the experimental diets compared with the unfermented sundried cassava meal. The nutrient value, crude protein $(11.4 \%)$, crude fibre (20.9) and lipid (3.5\%) of the ensiled cassava peel meal were significantly higher $(p<0.05)$ than those of the unfermented sun-dried cassava peel meal (crude protein, $5.3 \%$; crude fibre, 7.1 ; lipid, $1.2 \%$ ). The experimental feed was thus formulated based on the crude protein content $(11.4 \%)$ of the cassava peel. Table 3 shows the cyanide and phytate component of the unfermented cassava peel meal and ECPM used for compounding the diets. The APD of the various diets is shown in Table 4.

Figure 1 graphically illustrates the weekly growth pattern of the fish fed with the various diets. The fish fed with the control diet performed significantly $(p>0.05)$ better than the other treatments. The growth performance of the fish fed with diets B25 and C50 were better than that of the fish fed diets D75 and E100. Table 5 shows the weekly average body weight of $C$. gariepinus fed the control and the experimental diets. The final weight gain $(13.47 \mathrm{~g})$, daily weight gain $(0.19 \mathrm{~g})$, percentage weight gain $(243 \%)$ of the fish fed with the control diet were significantly $(p<0.05)$ 
Table 3. The anti-nutritional factors (anf) in cassava peel meal (cpm).

\begin{tabular}{lcc}
\hline ANF & Unfermented CPM & Fermented CPM \\
\hline Cyanide $\left(\mathrm{mg} \mathrm{kg}^{-1}\right)$ & 45.1 & 23.5 \\
Phytate $\left(\mathrm{mg} \mathrm{100g}^{-1}\right)$ & 1012 & 698 \\
\hline
\end{tabular}

Table 4. The apd (\%) recorded for the various diets fed to C. gariepinus fish.

\begin{tabular}{lccccc}
\hline Diets & A0 & B25 & C50 & D75 & E100 \\
\hline APD $(\%)$ & $90.1^{\mathrm{a}}$ & $87.7^{\mathrm{ab}}$ & $86.2^{\mathrm{b}}$ & $79.5^{\mathrm{c}}$ & $77.3^{\mathrm{c}}$ \\
\hline
\end{tabular}

Means with the same superscript on the same row are not significantly different ( $p>0.05)$ from one another).

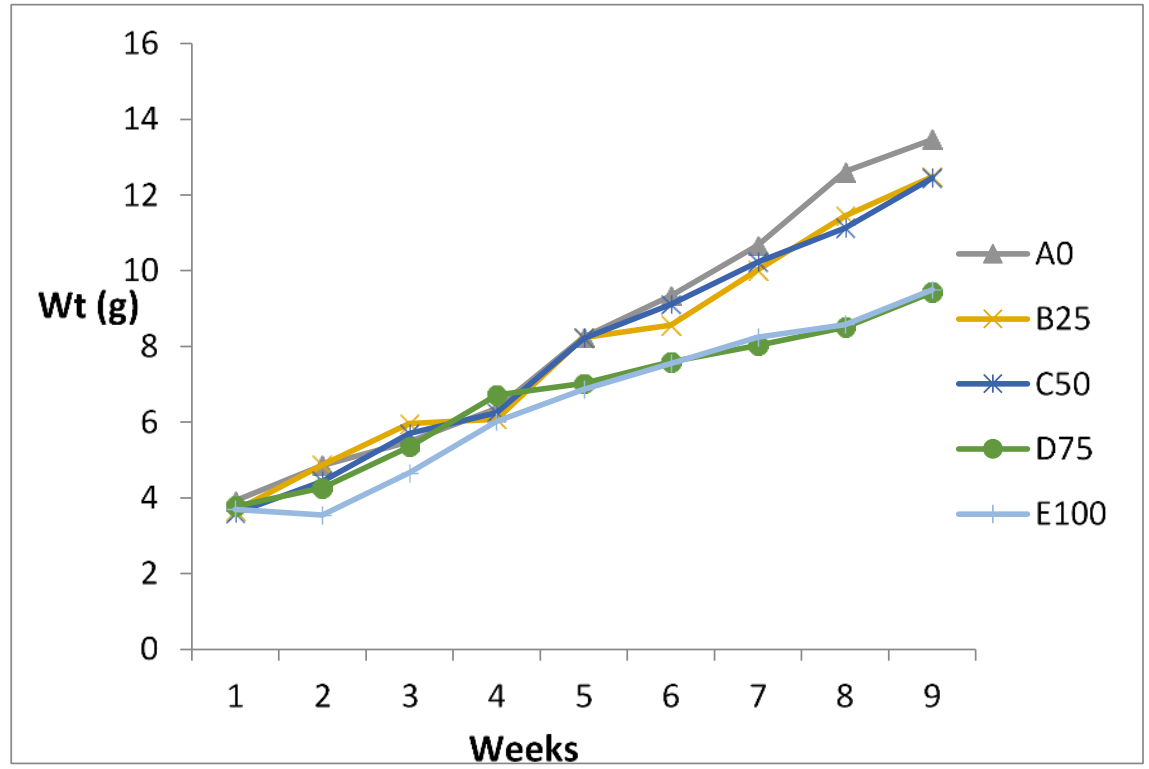

Figure 1. The weekly growth performances of $C$. gariepinus fed $M$. esculenta diets.

different from those of the fish fed with diets D75 and E100, but not significantly different $(p>0.05)$ from those of the fish fed diets B25 and C50.

All the fish fed the dietary treatment survived. The survival rate of the fish fed the trial diets, except treatment E100, compared favourably with that of the control treatment. As shown in Table 5, there was no significant difference $(p>0.05)$ between the specific growth rate recorded for any of the groups fed the control and the test diets. The food conversion ratio (FCR) of the fish fed with the control diet was significantly higher $(p<0.05)$ than those of the other diets. Among the fish groups fed with the cassava-meal based diets, the FCR of the fish fed diet B25 was the poorest.

Table 6 shows the proximate composition of the flesh of fish fed the experimental diets. The fat content (14.49\%) of the fillet of the fish fed the control diet was lower, but not significantly different from those of the fish fed B25 $(16.54 \%)$ and C50 (15.30\%). However, it is significantly different $(p<0.05)$ from the fat content recorded for the fish fed with diets D75 (12.79\%) and E100 (12.32\%). Protein content of the flesh of the experimental fish decreased as the cassava load of test diet increased. Therefore, the control diet produced fish with flesh containing crude protein content of $65.57 \%$ while diet E100, which has a $100 \%$ ECPM supplement produced fish with the lowest protein content of $61.56 \%$. The crude protein contents of fish fed with the control diet were, however, not significantly different $(p>0.05)$ from those fed with diets B25 and C50.

Moisture contents of the fillets of the fish increased as the cassava meal component of the feed increased. The moisture content of the fillets of fish fed with the control diet was significantly lower $(p>0.05)$ than the ones recorded for the fish fed with diets C50, D75 and E100, but not significantly different $(p>0.05)$ from those of the fish fed B25. The ash content of the fillets of fish fed with the control diet was significantly higher $(p<0.05)$ than the ones 
Table 5. Growth performance, food conversion and survival of the experimental fish.

\begin{tabular}{lccccc}
\hline \multirow{2}{*}{ Parameters } & \multicolumn{5}{c}{ Diet } \\
\cline { 2 - 5 } & A0 & B25 & C50 & D75 & E100 \\
\hline Mean Initial Wt (g) & $3.92^{\mathrm{a}}$ & $3.32^{\mathrm{b}}$ & $3.59^{\mathrm{b}}$ & $3.78^{\mathrm{a}}$ & $3.70^{\mathrm{a}}$ \\
Mean Final Wt (g) & $13.47^{\mathrm{a}}$ & $12.92^{\mathrm{a}}$ & $13.79^{\mathrm{a}}$ & $9.43^{\mathrm{b}}$ & $9.78^{\mathrm{b}}$ \\
Mean Wt Gain (MWG) (g) & $9.55^{\mathrm{a}}$ & $9.60^{\mathrm{a}}$ & $8.20^{\mathrm{ab}}$ & $5.65^{\mathrm{b}}$ & $6.08^{\mathrm{b}}$ \\
Daily Wt Gain (DWG) (g) & $0.19^{\mathrm{a}}$ & $0.17^{\mathrm{a}}$ & $0.14^{\mathrm{ab}}$ & $0.10^{\mathrm{b}}$ & $0.11^{\mathrm{b}}$ \\
\% Weight gain (PWG) & $244^{\mathrm{a}}$ & $289^{\mathrm{a}}$ & $274^{\mathrm{a}}$ & $149^{\mathrm{b}}$ & $164^{\mathrm{c}}$ \\
Survival rate (\%) & $100^{\mathrm{a}}$ & $95^{\mathrm{a}}$ & $96^{\mathrm{a}}$ & $100^{\mathrm{a}}$ & $89^{\mathrm{a}}$ \\
FCR & $1.67^{\mathrm{a}}$ & $1.70^{\mathrm{b}}$ & $1.82^{\mathrm{b}}$ & $1.79^{\mathrm{b}}$ & $1.84^{\mathrm{c}}$ \\
Specific Growth Rate (SGR) & $1.17^{\mathrm{a}}$ & $1.15^{\mathrm{a}}$ & $1.17^{\mathrm{a}}$ & $1.09^{\mathrm{a}}$ & $1.06^{\mathrm{a}}$ \\
\hline
\end{tabular}

Means with the same letters on a row are not significantly different $(p>0.05), \mathrm{Wt}=$ weight.

Table 6. The proximate composition ( $\% \mathrm{dm}$ ) of the fillets of the fish fed the test diets.

\begin{tabular}{lccccc}
\hline \multirow{2}{*}{ Proximate composition } & \multicolumn{5}{c}{ Diet } \\
\cline { 2 - 6 } & $\mathbf{A 0}$ & $\mathbf{B 2 5}$ & $\mathbf{C 5 0}$ & $\mathbf{D 7 5}$ & $\mathbf{E 1 0 0}$ \\
\hline Moisture (\%) & $8.87^{\mathrm{cd}}$ & $11.28^{\mathrm{c}}$ & $10.74^{\mathrm{c}}$ & $15.19^{\mathrm{ab}}$ & $20.00^{\mathrm{a}}$ \\
Fat (\%) & $14.49^{\mathrm{a}}$ & $16.54^{\mathrm{b}}$ & $15.30^{\mathrm{ab}}$ & $12.79^{\mathrm{c}}$ & $12.32^{\mathrm{c}}$ \\
Ash (\%) & $11.44^{\mathrm{a}}$ & $13.72^{\mathrm{a}}$ & $8.31^{\mathrm{b}}$ & $5.55^{\mathrm{c}}$ & $1.95^{\mathrm{d}}$ \\
Crude protein (\%) & $65.57^{\mathrm{a}}$ & $64.70^{\mathrm{a}}$ & $64.42^{\mathrm{ab}}$ & $62.36^{\mathrm{b}}$ & $61.56^{\mathrm{b}}$ \\
Carbohydrate (\%) & $4.23^{\mathrm{d}}$ & $5.50^{\mathrm{d}}$ & $6.73^{\mathrm{bd}}$ & $14.11^{\mathrm{a}}$ & $14.86^{\mathrm{a}}$ \\
\hline
\end{tabular}

Means with the same letters on a row are not significantly different $(p>0.05) . d m=$ dry matter.

recorded for the fish fed with diets C50, D75 and E100, but not significantly different $(p>0.05)$ from that of the fish fed B25. The carbohydrate content of the fillets of fish fed with the control diet was significantly lower $(p<0.05)$ than the ones recorded for the fish fed with diets C50, D75 and $E 100$, but not significantly different $(p>0.05)$ from those of the fish fed B25.

From the proximate analysis of the diets, it was observed that the composition of each of the experimental diets fed to $C$. gariepinus fish contained adequate nutrients, and were all highly digestible (77.3 to $90.1 \%$ ). These qualities were able to facilitate the growth of the fish. This agrees with Oboh et al. (2002) who observed that fermentation of cassava peel with Aspergillus niger, has the capability to increase the nutritional potential of cassava products by increasing the protein and fat contents and decreasing the level of cyanide and tannin (anti-nutrients) present in them.

However, the different growth rate recorded were probably due to the different levels of maize in the diets and residual level of cyanide/phytates. Cassava root meal is deficient in essential fatty acids. Hudson and Ogunsua (1974) reported that fat in cassava tuberous roots contains $1.46 \%$ linoleic acid, which is low compared to the $60.8 \%$ in maize (Hilditch and Williams, 1974). Omole (1977) also reported that under practical condition, linoleic acid may be sub-marginal in cassava root meal diets.

Fermentation of the cassava peels with waste water from the fermented cassava pulp might have significantly $(p<0.05)$ reduced the cyanide content of the cassava peels (23.5 mg kg-1) when compared with the unfermented cassava peels $\left(44.6 \mathrm{mg} \mathrm{kg}^{-1}\right)$. This shows that the microorganisms in the waste water were capable of partially degrading cyanogenic glucosides and the breakdown products. The cyanide level attained in this work however compares with $25 \mathrm{mg} \mathrm{kg}^{-1}$ in a cassava product, 'fufu' consumed by man. This level can be considered fairly safe in terms of cyanide poisoning in view of the fact that the cyanide was below the deleterious level of $30 \mathrm{mg} \mathrm{kg}^{-1}$ recommended by Tweyongyere and Katongole (2002). The decrease in the phytate content of the ECPM could be attributed to possible secretion of the enzyme phytase by the microorganisms in the waste-water (Duffus and JDuffus, 1991). The presence of traces of phytate and cyanide may however have impacted growth negatively. Phytates can chelate with di- and trivalent mineral ions such as $\mathrm{Ca}^{2+}, \mathrm{Mg}^{2+}, \mathrm{Zn}^{2+}, \mathrm{Cu}^{3+}$ and $\mathrm{Fe}^{3+}$ resulting in these ions becoming unavailable for consumers (Teskeredžić et al., 1995). A significant depression of zinc levels was observed in the carcass of juvenile rainbow trout fed with a diet containing undephytinised rapeseed protein concentrate (Liener, 1989). Since phytates cannot be broken down by nonruminants, their occurrence in feed reduces the availability of phosphorus to these animals (Ellestad et al., 2002; Richardson et al., 1985). Phytates form sparingly digestible phytate-protein complexes, thus reducing the availability of dietary protein (Oboh, 2006). Phytate in cassava peel could be up to $1 \% \mathrm{DM}^{-1}$ and natural fermentation, as done in this research could only reduce it to about $0.7 \% \mathrm{DM}^{-1}$.

All experimental diets fed to $C$. gariepinus contributed to the growth (SGR, MWG, PWG, FCR, PER) of the fish 
juveniles. The growth performance and proximate composition of the carcass improved in diet supplementation for up to $50 \%$ replacement. The control diet and diets with up to $50 \%$ cassava meal inclusion were probably more palatable. The high ash content in the control and test diets B25 (11.44\%, 13.72\% respectively) indicated high mineral content which is also advantageous to growth in the fish. These good growth observations might also have much to do with the protein quality of the diets. The rate of growth of an animal is a fairly sensitive index of protein quality. Weight gain is proportional to the supply and bioavailability of the essential amino acids in the diets.

Based on the result of this study, the substitution of maize with ECPM in the diets of $C$. gariepinus, at the inclusion levels of $75 \%$ and $100 \%$ were poor when compared with the control and diets B25 and C50. These findings agreed with the findings of Olurin et al. (2006) who reported that substituting maize with cassava in $C$. gariepinus fingerlings diet recorded optimum growth and nutrient utilization. Similar patterns of growth have been reported in the mirror carp and trout fed with different levels of cassava. The ability of mirror carp fingerlings to accept high quantities of cassava in diet was reported by Ufodike and Matty (1983). Other investigations have observed favourable growth in Oreochromis niloticus (Fagbenro and Arowosoge, 1991) and C. gariepinus (Faturoti and Akinbote, 1986) fed with ECPM based diets. The results disagree with Olurin et al. (2006) who recommended a complete $100 \%$ replacement of maize with ECPM. This report, negates the observation of Mgbenka et al. (2004) who reported that feeding cassava peel meal of up to $30 \%$ to young tilapia (Oreochromis niloticus) decreased performance and recommended a maximum inclusion rate of $10 \%$ for feeding tilapia.

The findings of the above authors (Fagbenro and Arowosoge, 1991; Faturoti and Akinbote, 1986; Olurin et al., 2006; Mgbenka et al., 2004) also agree with the observation on the processing method and the need for methionine supplement, as used in this study. Although the HCN content of cassava peel is higher than that of the root, feeding relatively high levels of ECPM did not seem to cause any problems of hydrocyanic toxicity, especially when the diet is supplemented with methionine. The quality and utilization of the dietary protein, in a properly balanced diet, could be improved through the addition of methionine to cassava-based rations (Adegbola, 1977). Adegbola (1977) revealed that the methionine served as detoxicant of any prussic acid released during the hydrolysis of linamarin and lotaustralin in the cassava meal/flour thereby increasing feed palatability. They further reported that without methionine supplementation, birds deteriorate in weight gain at three weeks of age, with significant differences in feed conversion efficiency when cassava levels exceed $20 \%$. Methionine is a metabolizable essential amino acid that also yields cystine which could improve performance. Adegbola (1977) maintained that it is desirable to feed methionine or fat supplements along with cassava peel meal to enhance the utilization of the feed and further emphasized that if no supplement is fed, the peel should not constitute more than $33 \%$ of the diet.

In an experiment with pigs, on the contrary, Job (1975) reported that the thiocyanate level, in serum and urine of rabbits, were not influenced when cassava peel meals were supplemented by methionine. Manner and Gomez (1973) noted an increase in urinary thiocyanate level while feeding rats on methionine-supplemented cassava-based diets. It seems that supply of sulfur for HCN detoxification of cassava-based diets could take place only by supplying sulfur-amino acid in the diet.

Factors that might be responsible for recorded level of mortality in some of the fish tanks, may include the effects of the remnant of cyanide and phytate in the blood, which was not monitored in this work, and stress due to handling. It is recommended that further work be done to include analysis of the effects of these diets on the haematology and serum biochemistry of the fish. Hematological parameters are good indicators of physiological status of animals and have been found useful for disease prognosis and for therapeutic and feed stress monitoring. Ngiki et al. (2014) maintained that it should also be noted that the nutritive content and value of cassava meal in livestock feed depends on the cassava variety used, the age of the cassava tuber, and the processing technology used in producing the cassava meal.

\section{CONFLICT OF INTEREST}

The author declares that there is no conflict of interest.

\section{Conclusion}

These results show that fermentation of cassava peels with wastewater from the fermented cassava pulp significantly reduced the phytate and cyanide contents of the cassava peels, thus making it more tolerable. The growth parameters (weight gain, FCR, SGR) and the APD of the fish fed diets B25 and C50 compare favourably with fish fed the control diet. Considering the growth data and biochemical attributes, it is recommended that cassava peel be fermented to improve nutrient quality of the meal and that, a replacement beyond $50 \%$ should be discouraged as replacement beyond this optimum value have indicated poor growth performance and could cause physiological disorder. This research revealed that maize meal can be replaced with up to $50 \%$ fermented cassava peel meal in the diet of Clarias gariepinus, without deleterious effects. For a more comprehensive report, further work should be done to analysis the effect of cyanide/phytate content of the feed on the haematology and fish blood serum.

\section{REFERENCES}

Achinewhu, S. C., Barber, L. I., \& ljeoma, I. O. (1998). Physico- 
chemical properties and garification (gari yield) of selected cassava cultivars in Rivers State, Nigeria. Plant Foods for Human Nutri. 52(2), 133-140.

Adegbola, A. A. (1977). Methionine as an additive to cassavabased diets. In: Proceedings of the Workshop on Cassava as Animal Feed. NestelBand GrahamM (eds.), University of Guelph, 18-20 April 1976, Ontario, Canada.IDRC Ottawa. Pp. 9-17.

Adewumi, A. A., \& Fagbenro, O. A. (2010). Fisheries and aquaculture development in Nigeria: An appraisal. Proceedings of 2010 International Conference for Bioinformatics and Biomed. Tech., China. April, 2010; 5p.

Adeyemo, O. K. (2005). Haematological and histopathological effects of cassava mill effluent on C. gariepinus. Afri. J. of Biomed. Res., 8, 179 -183.

Antai, S. P., \& Mbongo, P. M. (1994). Utilization of cassava peels as substrate for crude protein formation. Plant Foods for Human Nutri. 46(4), 345-351.

AOAC (Association of Official Analytical Chemists) (2006). Official methods of Analysis. 17 $7^{\text {th }}$ Edition. Williams S. (Ed.). Arlington, V.A. 1125p.

Aro, S. O., Aletor, V. A., Tewe, O. O., \& Agbede, J. O. (2010). Nutritional potentials of cassava tuber wastes: A case study of a cassava starch processing factory in south-western Nigeria. Livestock Res. for Rural Development, 22(11), 42-47.

Charles, A. L., Sriroth, K., \& Huang, T. C. (2005). Proximate composition, mineral contents, hydrogen cyanide and phytic acid of 5 cassava genetypes. Food Chem., 92, 615-620.

Cumbana, A., Minone, E., Cliff, J., \& Bradbury, J. H. (2007). Reduction of cyanide content of cassava flour in Mozambique by wetting method. Food Chem., 101, 894-897.

Duffus, C. M., \& Duffus, J. H. (1991). Toxicity of cassava. In: D'Mello FJP Duffus CM and JH Duffus (Eds). Toxic Substances in Crop Plants. The Royal Society of Chemistry, Thomas Graham House, Science Park, Cambridge CB4 4WF, Cambridge. Pp. 1-21.

Ellestad, L. E., Angel, R. J. R. J. S., \& Soares, J. H. (2002). Intestinal phytase II: a comparison of activity and in vivo phytate hydrolysis in three teleost species with differing digestive strategies. Fish Physiol. and Biochem. 26(3), 259273.

Fagbenro, O. A., \& Arowosoge, I. A. (1991). Replacement value of some household wastes as energy substitutes in low-cost diets for rearing catfish in South-Western Nigeria. Bioresource Tech., 37(3), 197-203.

Faturoti, E. O., \& Akinbote, R. E. (1986). Growth response and nutrient utilization in Oreochromis niloticus fed varying levels of dietary cassava peel. Nigerian Journal of Applied Fisheries and Hydrobiology, 1, 47-50.

Hilditch, T. P., \& Williams, P. N. (1974). The Chemical Constitution of Natural Fats. $4^{\text {th }}$ edition. Chapman and Hall. London. p. 45.

Hudson, B. I. F., \& Ogunsua, A. O. (1974). Lipids of cassava tuberous roots (Manihot esculenta Crantz). J.of the Sci. of Food and Agric., 25, 1503-1508.

Job, T. A. (1975). Utilization and protein supplementation of cassava for animal feeding and the effects of sources on cyanide detoxification. A Ph.D Thesis, University of Ibadan, Ibadan, Nigeria. 540p.

Liener, I. E. (1989). Antinutritional factors in legume seeds: state of the art. Recent Advances of Research in Anti-nutritional factors in legume seeds, Pp. 6-13.

Manner, J. H., \& Gomez, G. (1973). Implications of cyanide toxicity in animal feeding studies, using high cassava rations.
In: Proceedings of Chronic Cassava Workshop. Nestle B and R Maclntyre (Eds.), 29-30 ${ }^{\text {th }}$ Jan., 1973, London, England. IDRC Ottawa. Pp. 113-120.

Mgbenka, B. O., Ugwu, L. L. C., \& Asogwa, M. O. (2004). Influence of dietary levels of cassava (Manihot esculenta) peel meal on feed efficiency and productive protein value of young tilapia (Oreochromis niloticus, Trewavas). J. of Sustainable Agric. and the Environ. 6(2), 148-156.

Montagnac, J. A., Davis, C. R., \& Tanumihardjo, S. A. (2009). Nutritional value of cassava for use as a staple food and recent advances for improvement. Comp. Rev. in Food Sci. and Food Safety, 8(3), 181-194.

Motarjemi, Y. (2002). Impact of small scale fermentation technology on food safety in developing countries. Intern. J. of Food Micro., 75(3), 213-229.

Nwokoro, S. O., Adegunloye, H. D., \& Ikhinmwin, A. F. (2005). Nutritional composition of garri sievates collected from some locations in Southern Nigeria. Pakistan J. of Nutr., 4(4), 257261.

Oboh, G. (2006). Nutrient enrichment of cassava peels using a mixed culture of Saccharomyces cerevisae and Lactobacillus spp solid media fermentation techniques. Electronic J. of Biotech., 9(1), 46-49.

Oboh, G., Akindahunsi, A. A., \& Oshodi, A. A. (2002). Nutrient and anti-nutrient content of Aspergillus niger fermented cassava products (flour and gari). J. of Food Comp. and Anal., 15(5), 617-622.

Olurin, K. B., Olojo, E. A. A., \& Olukoya, O. A. (2006). Growth of African catfish, C. gariepinus fingerlings, fed different levels of cassava. World J. of Zool., 1(1), 54-56.

Omole, T. A. (1977). Cassava in the nutrition of layers. In: Cassava as Animal feed. Proceedings of Cassava as Animal Feed Workshop. Nestle B and Graham M. (Eds), University of Guelph, Canada. IDRC Ottawa. 18-20th April, 1977. Pp. 5155.

Phonekhampheng, O., Hung, L. T., \& Lindberg, J. E. (2008). Nutritive value of potential feed resources used in Laos for African catfish (Clarias gariepinus) production. Livestock Research for Rural Development, 20, Article 207.

Richardson, N. L., Higgs, D. A., Beames, R. M., \& McBride, J. R. (1985). Influence of dietary calcium, phosphorus, zinc and sodium phytate level on cataract incidence, growth and histopathology in juvenile chinook salmon (Oncorhynchus tshawytscha). The Journal of nutrition, 115(5), 553-567.

Saha, D. C., \& Gilbreath, R. L. (1991). Analytical recovery of chromium from diet and faeces determined by colorimetry and atomic absorption spectrophotometry. Journal of the Science of Food and Agriculture, 55(3), 433-446.

Sengxayalth, P., \& Preston, T. R. (2017). Fermentation of cassava (Manihot esculenta Crantz) pulp with yeast, urea and di-ammonium phosphate (DAP). Liv. Res. For Rural Dev., 29(9) http://www.Irrd.org//rrd29/9/pom29177.html

Teskeredžić, Z., Higgs, D. A., Dosanjh, B. S., McBride, J. R., Hardy, R. W., Beames, R. M., Jones, J. D., Simell, M., Vaara, T., \& Bridges, R. B. (1995). Assessment of undephytinized and dephytinized rapeseed protein concentrate as sources of dietary protein for juvenile rainbow trout (Oncorhynchus mykiss). Aquaculture, 131(3-4), 261-277.

Tewe, O. O. (1992). Detoxification of cassava products and effects of residual toxins on consuming animals. Roots, tubers, plantains and bananas in animal feeding (Editors: D Machin and AW Speedy). FAO Animal Production and Health. Paper, 95, 85-91.

Tweyongyere, R., \& Katongole, I. (2002). Cyanogenic potential 
of cassava peels and their detoxification for utilization as livestock feed. Veterinary and human toxicology, 44(6), 366369.

Ufodike, E. B. C., \& Matty, A. J. (1983). Growth responses and nutrient digestibility in mirror carp (Cyprinus carpio) fed different levels of cassava and rice. Aquaculture, 31(1), 41-50.
Wheeler, E. L., \& Ferrel, R. E. (1971). A method for phytic acid determination in wheat and wheat fractions. Cereal chemistry, 48(3), 312-320. 